J. MAXWELL ANDERSON AND K. BENIRSCHKE: MATERNAL TOLERANCE OF FOETAL TISSUE

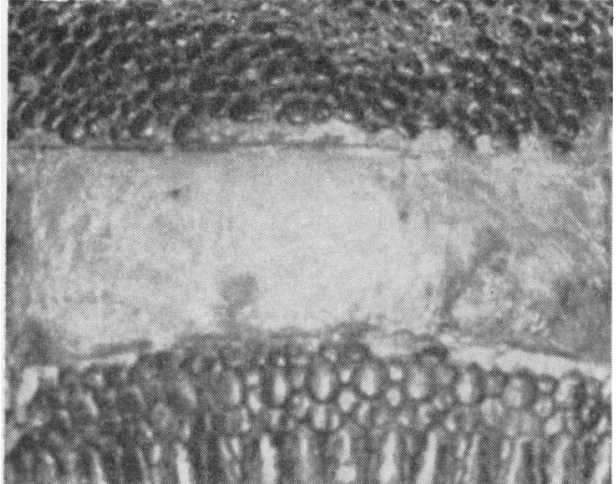

Fig. 1.-Skin transplant site on day 35. The righthand part of the shell defect shows an unrelated foetal transplant which was rejected on day $12 ;$ it is covered with spread epithelium from the surviving specific foetal transplant on the left.
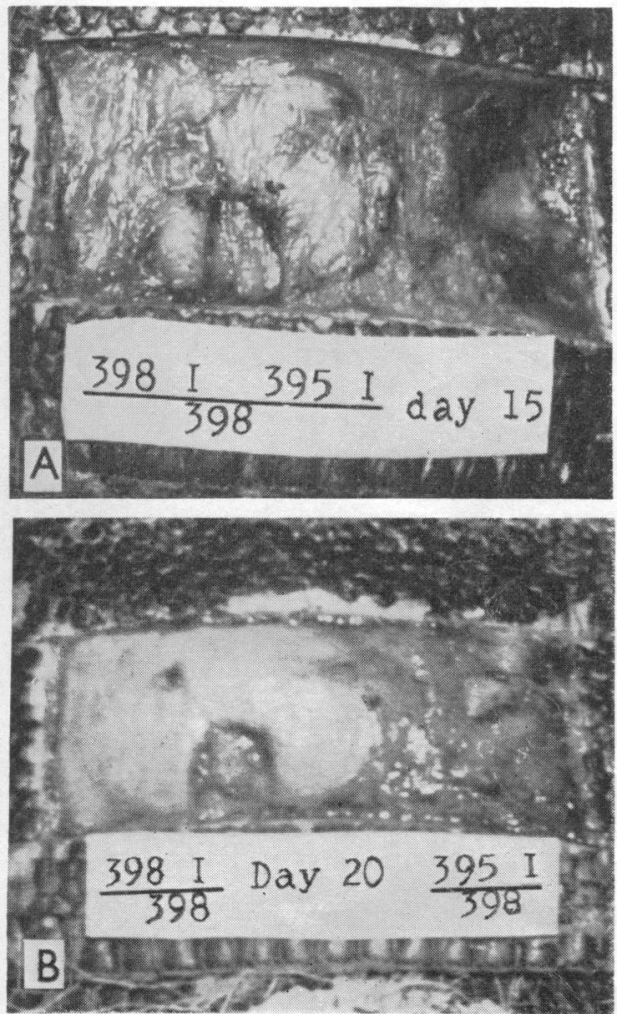

FIG. 2.-Same transplants as in Fig. 1: A on day $15 ; \mathrm{B}$, on day 20. On the right is granulation tissue in the bed of the rejected unrelated foetal transplant. On the left is the host's own foetal transplant; in $B$ it is recovering from an abortive homofrom an abortive homograft reaction and is slightly swollen. At its lower border is a biopsy defect containing
pinch autograft.

FIG. 4.-Anterior abdominal wall of the host bearing tumours of embryonic tissues. In the midline the thin operation scar extends caudally from the umbilicus. On each side bilicus. On each side
of the scar are the solid tumours.

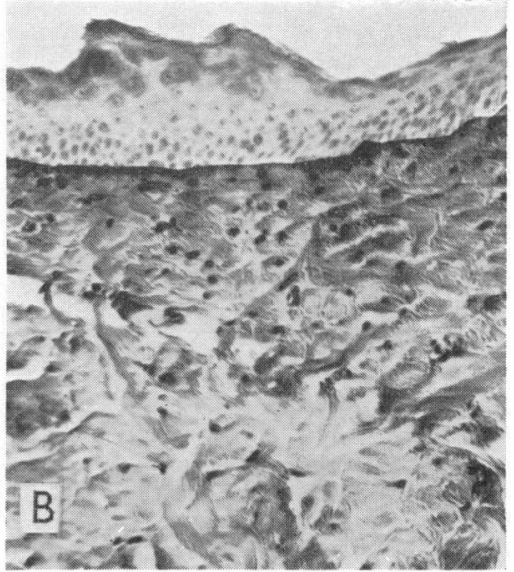

$\underline{\underline{T}}$

c

䎡

음

क्ष

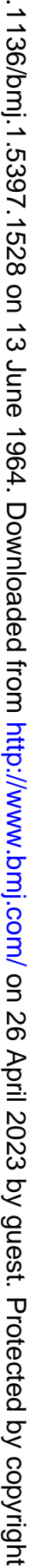
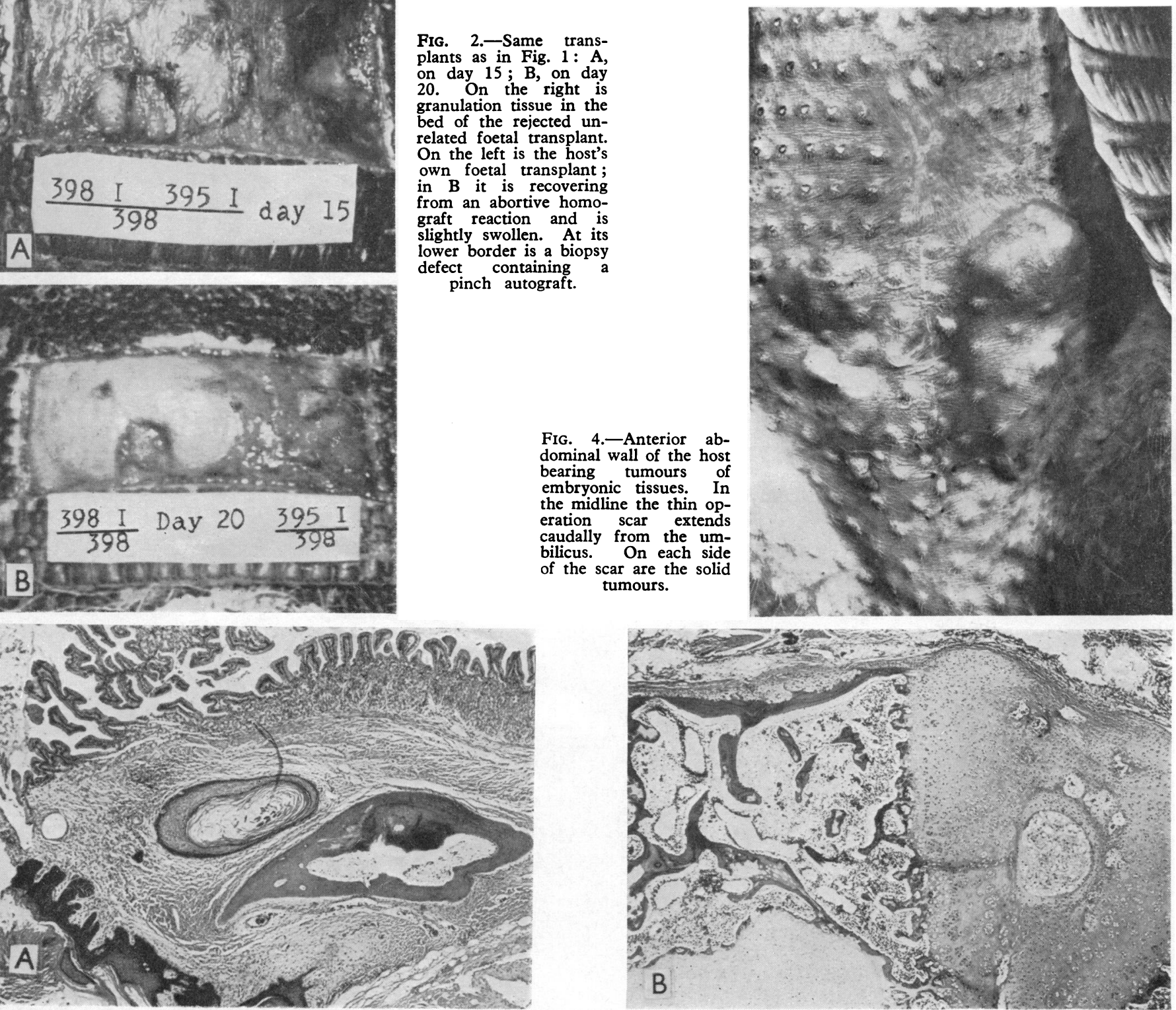

FIG. 5.-Photomicrographs of representative sections from the tumours shown in Fig. 4. A stomach wall is present at the top, with keratinproducing epidermis at the centre and bottom left. B, one of the many pieces of well-formed bone, with a definite marrow-containing cavity and adjacent cartilage containing notochord. (Haematoxylin and eosin. $\times 30$.) 


\title{
Maternal Tolerance of Foetal Tissue
}

\author{
J. MAXWELL ANDERSON,*† M.B., F.R.C.S., F.R.C.S.ED. ; K. BENIRSCHKE,* M.D.
}

[With Special Plate]

Brit. med. F., 1964, 1, 1534-1535

An investigation of the immunological paradox of mammalian viviparous reproduction has led to a study of the fate of skin transplants from young adult, newborn, and foetal armadillos to their mothers. The monozygotic quadruplets of the ninebanded armadillo of Texas, Dasypus novemcinctus mexicanus Peters, are particularly useful in this context when they are in utero. Removal of one foetus only at hysterotomy and immediate transplantation of its belly skin to the mother results in a dual existence of foetal tissues, upon the body wall and within the uterus of a pregnant animal. Extensive experiments with the armadillo are difficult because laboratory breeding has not been successful. However, the interest of the early results and the implications for human biology prompt this preliminary account.

\section{Experimental Design}

Six control transplants between unrelated adult armadillos weighing 2.5 to $4.5 \mathrm{~kg}$. were made by the technique previously described (Anderson and Benirschke, 1962).

After developing a suitable technique of aseptic hysterotomy (Anderson and Benirschke, 1963, unpublished work) the effect of the operation at different stages of pregnancy was tested. Normal delivery of the remainder of the conceptus followed the removal of one, two, or even three of the foetuses.

Knowing the survival times of three pairs of skin transplants between 6-month-old offspring and their mothers (Anderson and Benirschke, 1962), the following programme was devised to study the immunological relationships of the mother and foetus during pregnancy and immediately post partum.

Skin from foetuses removed at hysterotomy was transplanted to seven unrelated non-pregnant females, to two mothers of donors, and to one unrelated gravid female. All the foetuses weighed 70 to $100 \mathrm{~g}$., the weight of a mature newborn armadillo being approximately $100 \mathrm{~g}$. Two transplants were made from 1-week-old offspring to their mothers : a cellular suspension, prepared from the vertebrae and the viscera excluding the intestine of one donor, was injected into the muscles and subcutaneous tissues of the anterior abdominal wall of the mother. This infusion was given as part of another study to observe its effects upon the remainder of the conceptus.

\section{Results}

The six transplants between unrelated adults were rejected after 14 to 20 days, with a mean survival time of 16.5 days. Transplants from 6-month-old offspring to their mothers survived 21 to 27 days, with a mean survival time of 24 days, and the maternal transplants on 6-month-old offspring survived 21 to 32 days, with a mean survival time of 26.3 days (Table I).

Table II shows the other results. Seven foetal homotransplants to unrelated non-pregnant females were all rejected after 11 to 13 days, with a mean survival time of 12.1 days. The two

\footnotetext{
* Department of Pathology, Dartmouth Medical School, Hanover, Ner Hampshire, U.S.A.

† Present address : Stobhill General Hospital, Glasgow.
}

foetal transplants to the mothers still bearing three members of the conceptuses at the time of transplantation survived 32 days or 8 days post partum, and 35 days or 32 days post-partum (Special Plate, Fig. 1) respectively. The former host died of intestinal obstruction by an adhesion at the uterine scar, and the latter of pneumonia. Both transplants showed a modified homograft reaction for two or three days two weeks after transplantation. This resolved and the appearances thereafter were as of autografts. The transplant from an unrelated foetus on one of these mothers was rejected in 12 days; its appearances on days 15 and 20 are shown in Fig. 2 (Special Plate).

TABLE I.-Survival Time of Transplants Between Unrelated Adult Armadillos and Between 6-month-old Offspring and Their Mothers

\begin{tabular}{|c|c|c|c|c|}
\hline \multirow{2}{*}{\multicolumn{2}{|c|}{ Type of Transplant }} & \multirow{2}{*}{ No. } & \multicolumn{2}{|c|}{ Survival Time (Days) } \\
\hline & & & Range & Mean \\
\hline $\begin{array}{l}\text { Adult to unrelated adult } \\
\text { 6-month-old offspring to mother } \\
\text { Mother to 6-month-old offspring }\end{array}$ & $\ddot{\cdots}$ & $\begin{array}{l}6 \\
3 \\
3\end{array}$ & $\begin{array}{l}14 \text { to } 20 \\
21,27 \\
21,32\end{array}$ & $\begin{array}{l}16 \cdot 5 \\
24 \cdot 0 \\
26 \cdot 3\end{array}$ \\
\hline
\end{tabular}

TABLB II.-Fates of Foetal and Newborn Skin Transplants

\begin{tabular}{|c|c|c|c|}
\hline Type of Transplant & No. & $\begin{array}{c}\text { Survival } \\
\text { Time } \\
\text { (Days) }\end{array}$ & Comment \\
\hline $\begin{array}{l}\text { Foetus to unrelated } \\
\text { non-pregnant female }\end{array}$ & 7 & $\begin{array}{c}11 \text { to } 13 \\
32\end{array}$ & $\begin{array}{l}\text { Mean survival time } 12 \cdot 1 \text { days. All } \\
\text { destroyed by homograft reaction } \\
\text { Died of intestinal obstruction } 8 \text { days } \\
\text { after normal birth of three } \\
\text { remaining offspring, and } 32 \text { days } \\
\text { after hysterotomy and skin trans- } \\
\text { plantation }\end{array}$ \\
\hline Foetus to mother $\quad \cdots$ & 2 & 35 & $\begin{array}{l}\text { Died of pneumonia } 32 \text { days after } \\
\text { normal birth of three remaining } \\
\text { offspring, and } 35 \text { days after } \\
\text { hysterotomy and skin transplanta- } \\
\text { tion }\end{array}$ \\
\hline $\begin{array}{l}\text { Foetus to unrelated } \\
\text { gravid female }\end{array}$ & 1 & 12 & Destroyed by homograft reaction \\
\hline $\begin{array}{l}\text { 1-week-old newborn } \\
\text { to mother }\end{array}$ & 2 & 329 & $\begin{array}{l}\text { Died of idiopathic peritonitis } 33 \text { days } \\
\text { after normal delivery and } 27 \text { days } \\
\text { after transplantation } \\
\text { Sacrificed with surviving transplant. } \\
\text { Tumours of embryonic tissue in } \\
\text { abdominal-wall sites of injection } \\
\text { of newborn cell suspension }\end{array}$ \\
\hline
\end{tabular}

One transplant from a 1-week-old offspring to its mother was surviving, though it was the site of a modified homograft reaction, when the host died from peritonitis of unknown origin 27 days after the transplantation. The other transplant from a 1-week-old offspring to its mother underwent a modified homograft reaction for a few days during the third week after transplantation, but survived until the host was sacrificed 329 days after the transplantation; it resembled an autograft macroscopically (Special Plate, Fig. 3A) and microscopically (Fig. $3 \mathrm{~B})$. This host had a number of tumours at the sites of injection of the cellular suspension into the anterior abdominal wall (Fig. 4).

Microscopy showed the predominant tissue in the tumours to be bone with marrow and cartilage. Good joints, notochord, scutes, and toenails were present. Skin, oesophagus, and stomach were well preserved, there being an ulcer in one part of the gastric epithelium examined. Ciliated epithelium and mucus-filled cysts lined with columnar epithelium were also 
seen. All the structures were well differentiated, and, with the exception of some foreign-body giant-cell reaction to keratin, there was no inflammation (Special Plate, Figs. 5A and $\mathrm{B}$ ).

The operations and the cellular infusion had no effect on the pregnancies and the deliveries, which were normal as in the pilot series.

\section{Discussion}

Four noteworthy points are: (1) the consistent rejection of foetal skin on unrelated hosts, (2) the slightly prolonged survival of transplants between 6-month-old offspring and their mothers, (3) the survival of transplants from foetuses and newborns to their mothers, and (4) the association of a 329-day survival of a transplant from a 1-week-old offspring to its mother with tumours of embryonic tissue derived from the same donor as the skin.

Well-developed antigenicity of foetal skin was demonstrated by the rejection of the transplants to unrelated adult females and to the gravid female. Therefore antigenic immaturity cannot account for the absence of immune responses to foetal tissue at the relevant point of time in pregnancy, nor can it explain the survival of transplants from foetus to mother.

Prolonged survival of interchanged offspring-to-mother skin transplants has been described in man (Peer et al., 1958) and in the rat (Rogers et al., 1960). A similar result was obtained in the present study using 6-month-old offspring. Although the numbers are small, increases in the mean survival times of 7.5 and 9.8 days respectively occurred in both directions of transfer (see Table I). In some mammals, therefore, there are indications that a degree of mutual tolerance between offspring and mother results from pregnancy.

Since four transplants from foetuses and newborns to their mothers survived beyond the mean survival time of transplants from 6-month-old offspring to their mothers, it seems that maternal tolerance to foetal tissue is virtually complete during the few weeks before and after parturition. But six months later the specific response has recovered and offspring transplants are rejected. The abortive homograft reactions seen in foetal tissues transferred from intrauterine to extrauterine sites may represent a mild homograft reaction continuing during normal pregnancy. Possibly an immunological " mopping-up" process is effected in the placenta, or the trophoblast may form a barrier to active or potentially active vectors of an immune reaction. An immunological barrier function is indicated by claims for reduced antigenicity of trophoblast (Hasek et al., 1962; Simmons and Russell, 1962) and by the sensitization experiments of Woodruff (1957) and of Lanman et al. (1962). However, in this study the foetal tissues survived without the protection of a layer of trophoblast, and such a barrier would not account for the undoubted mitigation of the homograft reaction seen in the armadillo, the rat, and man.

Only further study can decide whether the single long-term survival was determined by a chance genetic similarity between the mother and her offspring.

The faculty of growth in transplanted embryonic tissues was demonstrated 80 years ago (Zahn, 1884), but prolonged survival and differentiation usually demands conditioning of the host by cortisone administration (Toolan, 1958) or irradiation, which presumably act by depressing the immune responses. In the present case pregnancy may be regarded as the conditioning agent, determining not only the prolonged survival and growth of the injected cell suspension but also the survival of the skin transplant. The influence of the embryonic tissues upon the survival of the skin transplant remains speculative and is worthy of study. But the long survival of offspring-to-mother transplants in this and other species (Peer et al., 1968 ; Rogers et al., 1960) weighs against the importance of factors additional to pregnancy in this context. As with the skin transplants, no barrier of trophoblast was necessary for survival of the embryonic tumours.

Erythrocytes containing foetal haemoglobin (Finn et al., 1963 ; Freese and Titel, 1963 ; Zipursky et al., 1963) and trophoblast cells (Bardawill and Toy, 1959) are found regularly in the human maternal circulation, and maternal erythrocytes can often be detected in umbilical cord blood (Smith et al., 1961). Thus, contrary to earlier beliefs, the transfer of many cells across the placenta is probably the normal condition. A gradually increasing volume of transfer during pregnancy, resulting in a degree of mutual tissue-tolerance between mother and foetus, is acceptable from many viewpoints as the principal explanation of mammalian viviparity. The rejection of all the transplants between 6-month-old armadillo offspring and their mothers demonstrates the impermanence of the proposed state of mutual immunological inertia; while their prolonged survival parallels the findings in man and the rat, showing that the recovery from the specific inert state may not be complete.

Although the evidence is good that the trophoblast forms an immunological barrier zone between the mother and foetus, the main factor allowing viviparous reproduction appears to be the acquisition of a temporary state of specific immunological maternal inertia to the tissues of the foetus.

\section{Summary}

An investigation of mammalian viviparity, using the monozygotic quadruplet pregnancy of the armadillo, has demonstrated prolonged survival of skin transplants from foetus to mother and delayed rejection of transplants between offspring and mother. Injected suspensions of embryonic cells formed organized embryonic tissue masses in the mother. No trophoblast barrier was present around the transplanted tissues. A temporary degree of mutual immunological tolerance, resulting from the interchange of circulating cells between the mammalian mother and her foetus, is upheld as the main mechanism of the anomaly of viviparity.

This work was supported by grants from the National Foundation and from the United States Public Health Service (GM.10210). We gratefully acknowledge the departmental facilities generously accorded for some of our early studies in Houston, Texas, by Dr. A. C. Enders, Dr. M. Desmond, Dr. T. Hoff, and Dr. L. Geddes. We also thank Dr. A. H. Imrie and Mrs. S. E. Maxwell Anderson for expert operative assistance, and Miss Lydia E. Brownhill for the preparation of cellular suspensions.

\section{REFERENCES}

Anderson, J. M., and Benirsctike, K. (1962). Ann. N.Y. Acad. Sci., 99, 399.

Bardawill, W. A., and Toy, B. L. (1959). Ibid., 80, 197.

Finn, R., Clarke, C. A., Donohoe, W. T. A., McConnell, R. B., Sheppard P. M., Lehane, D., and Kulke. W. (1961). Brit. med. f., 1, 1486.

- Harner D. T., Stallings, S. A., and Krevans, J. R. (1963). Trans fuszon (Paris), 3, 114.

Freese, U. E., and Titel, J. H. (1963). Obstet. and Gynecol., 22, 527.

Hasek, M., Haskova, V., Lengerova, A., and Vojtiskova, M. (1962). Transplantation, p. 118. Ciba Foundation Symposium, edited by G. E. W. Wolstenholme and M. P. Cameron. Churchili, London.

Lanman, J. T., Dinerstein, J., and Fikrig, S. (1962). Ann. N.Y. Acad. Sci., $99,706$.

Peer, L. A., Bernhard, W., and Walker, J. C. (1958). Amer. f. Surg., 95, 239.

Rogers, B. O., Raisbeck, A. P., Ballantyne, D. L., jun., and Converse, J. M. (1960). Trans. int. Soc. plast. Surg., p. 421.

Simmons, R. L., and Russell, P. S. (1962). Ann. N.Y. Acad Sci., 99, 717.

Smith, K., Duhring, J. L., Greene, J. W., jun., Rochlin, D. B., and Blakemore, W. S. (1961). Obstet. and Gynecol., 18, 673.

Toolan, H. W. (1958). Ann. N.Y. Acad. Sci., 73, 546.

Woodruff, M. F. A. (1957). Proc. roy. Soc. B, 148, 68.

Zahn, F. W. (1884). Virchows Arch. path. Anat., 95, 369.

Zipursky, A., Pollock, J., Neeland, P., Chown, B., and Israels, L. G. (1963). Lancet, 2, 489. 